\title{
In vitro effects of methylmercury on ascidian (Styela plicata) immunocyte responses
}

\author{
M. Cammarata ${ }^{1}$, M.G. Parisi ${ }^{1}$, G. Benenati ${ }^{1}$, V. Arizza1 ${ }^{1}$, T. Cillari ${ }^{1}$, D. Piazzese ${ }^{2}$, \\ A. Gianguzza ${ }^{2}$, M. Vazzana ${ }^{1}$, A. Vizzini ${ }^{1}$ and N. Parrinello ${ }^{1 *}$ \\ ${ }^{1}$ Marine Immunobiology Laboratory, Department of Animal Biology, University of Palermo, Via Archirafi 18, Palermo, Italy \\ ${ }^{2}$ Department of Inorganic and Analytical Chemistry, Viale delle Scienze Parco D'Orleans II-Padiglione 17, 90128 Palermo, Italy
}

Received 1 August 2007; Accepted 31 August 2007

\begin{abstract}
This study shows that high methylmercury concentrations are cytotoxic for Styela plicata hemocytes, whereas sublethal concentrations affect immunocyte responses. Moreover, hemocytes exposed to the xenobiotic present a significantly enhanced phenoloxidase activity as revealed in the hemocyte lysate supernatant compared with the control. Although the cytotoxic activity of S. plicata hemocytes toward rabbit erythrocytes is a PO-dependent cell-target reaction due to quinone products, it was significantly decreased by suitable methylmercury concentrations in the medium. The same xenobiotic concentrations decreased the hemocyte phagocytic activity toward yeast. In both the responses celltarget contacts could be affected by methylmercury, whereas the releasing capacity appeared to be unchanged, as indicated by hemocyte PO-release in the medium. Finally, changes in hemocyte shape and spreading capacity were shown. On the basis of the present results, Styela plicata hemocyte responses could be an additional immunotoxicology test using a microplate method that reveals cell morphological changes and spreading capacity. Copyright $\odot 2007$ John Wiley \& Sons, Ltd.
\end{abstract}

KEYWORDS: tunicate; ascidian; hemocytes; toxic metals; methylmercury; phenoloxidase; phagocytosis; cytotoxicity

\section{INTRODUCTION}

Pollution by heavy metals is a major risk in aquatic ecosystems, where high concentrations cause adverse biological effects, including changes in immune function of invertebrate and vertebrate species. ${ }^{1-3}$ In the marine environment, although mercury concentration in the water column and sediments may be low, filter feeding invertebrates accumulate this metal in their tissues. ${ }^{4}$ In addition, biological processes mediate mercury methylation, transforming the metal into methylmercury ${ }^{5-9}$ which is the most toxic form due to the methyl group that facilitates cell penetration and interaction with proteins, interfering with their synthesis and leading to lipid peroxidation. ${ }^{10}$ Methylmercury is capable of blocking the binding sites of enzymes while they interfere with the incorporation of thymidine into DNA. ${ }^{7}$

\footnotetext{
*Correspondence to: N. Parrinello, Marine Immunobiology Laboratory, Department of Animal Biology, University of Palermo, Via Archirafi 18, Palermo, Italy.

E-mail: nicpar@unipa.it

Contract/grant sponsor: MIUR.

Contract/grant sponsor: University of Palermo.
}

Mercury pollution in aquatic systems necessitates knowledge of the biological effects of methylmercury, ${ }^{9,11-13}$ which can be responsible for changes in immune functions ${ }^{1-3,14}$ of animals that accumulate heavy metals. In addition, with the increasing interest in using organisms as bioindicators for marine environmental chronic stress, ${ }^{15-17}$ cellular and functional parameters of the immune system in many sentinel species can represent anticipatory signals in monitoring organisms and their environment. ${ }^{18,19}$ Ascidians filter large amounts of water, accumulate toxicants in their tissues, including heavy metals, and are considered good indicators of water quality. ${ }^{20,21}$ However little is known about the effects of heavy metals on biological functions. Cima et al. ${ }^{22}$ reported that a treatment with organotin compounds decreased the viability of Styela plicata embryos, and other authors have shown that copper and tributyltin (TBT) affect cytotoxicity ${ }^{23}$ and phagocytosis. ${ }^{23-25}$

The general functional features of invertebrate and vertebrate phagocytes make phagocytic function attractive for immunotoxicology studies. Phagocytosis can be affected by environmental xenobiotics. ${ }^{18,24,26-31}$ Copper alters actin and fibronectin organization of mussel hemocytes, ${ }^{32}$ and heavy 
metals impair the phagocytic activity of coelomocytes from terrestrial and aquatic annelid species, ${ }^{33-35}$ chronic exposure to low doses of metallic mercury impaired the chemotactic activity of vertebrate polymorphonuclear leukocytes. ${ }^{36,37}$

The cascade reaction named 'prophenoloxidase activating system' (proPO) is an invertebrate melanogenic pathway involved in immune responses ${ }^{38-40}$ challenged by bacterial $\beta$ 1,3 glucans or lipopolysaccharides. A recognition phase starts a protease cascade that activates hemocyte prophenoloxidase, and the subsequent phenoloxidase (PO) pathway produces cytotoxic quinones and radical oxygen intermediates. ${ }^{41}$ Ascidian $\mathrm{PO}$ is a $o$-diphenoloxidase, detected in hemocyte lysates and identified in hemocytes by cytochemical analysis. ${ }^{42}$

In ascidians hemocyte, immunoreactivity could be affected by sublethal methylmercury concentration in the organism and/or in sea water. In the present paper, phagocytic and phenoloxidase activities of Styela plicata hemocytes appear to be affected by methylmercury. This xenobiotic, at high concentrations, is cytotoxic for hemocytes in vitro, whereas at sublethal concentration it affects S. plicata immunocyte activities, causing immunosuppression, as revealed by assays of phenoloxidase-dependent cytotoxic activity and phagocytosis. Finally, changes in hemocyte morphology and spreading capacity were shown.

\section{EXPERIMENTAL}

\section{Chemicals}

Methylmercury was first dissolved at $10^{-3} \mathrm{M}$ concentration in marine solution (MS: $12 \mathrm{mM} \mathrm{CaCl} \cdot 6 \mathrm{H}_{2} \mathrm{O} ; 11 \mathrm{mM} \mathrm{KCl}$; $26 \mathrm{~mm} \mathrm{MgCl}{ }_{2} 6 \mathrm{H}_{2} \mathrm{O} ; 45 \mathrm{~mm}$ Tris; $38 \mathrm{mM} \mathrm{HCl} ; 0.45 \mathrm{M} \mathrm{NaCl}$; $\mathrm{pH}$ 7.4). Stock solutions were then diluted in MS to the final concentrations of $10^{-8}, 10^{-7}, 10^{-6}, 10^{-5}, 10^{-4} \mathrm{M}$. Preliminary assays showed that the cell viability did not change as an effect of the methylmercury solvent. Unless otherwise reported, all the chemicals used were from Sigma (St Louis, MO, USA).

\section{Tunicates and preparation of hemolymph}

Ascidians (25-30 g wet weight) were collected from Mazara del Vallo Harbour (Sicily, Italy), maintained in tanks with aerated sea water at $15^{\circ} \mathrm{C}$, and fed every second day with a marine invertebrate diet (Hawaiian Marine Imports Inc., Houston, TX, USA).

The tunic was cleaned from epiphytes and sterilized with ethyl alcohol; the incurrent siphon was incised and the exuding hemolymph was collected into sterile tubes containing a 5-fold excess of calcium/magnesium-free artificial sea water (FSW: $9 \mathrm{mM} \mathrm{KCl} ; 0.15 \mathrm{M} \mathrm{NaCl} ; 29 \mathrm{mM}$ $\mathrm{Na}_{2} \mathrm{SO}_{4}, \mathrm{NaHCO}_{3}, \mathrm{pH}$ 7.4) with $10 \mathrm{~mm}$ EDTA (FSW-EDTA) as anticoagulant (1:9 medium:hemolymph ratio), on ice. After centrifuging at $400 \mathrm{~g}$ for $10 \mathrm{~min}$ at $4{ }^{\circ} \mathrm{C}$, the hemocytes were washed three times in sterile FSW-EDTA. Appropriate controls showed that hemocyte mortality evaluated by the Trypan blue test was lower than $5 \%$.

\section{Hemocyte lysate supernatant (HLS)}

Hemocytes $\left(3 \times 10^{6} \mathrm{ml}^{-1}\right)$ in ice-cold FSW-EDTA were centrifuged and suspended in a same volume of $10 \mathrm{mM}$ cacodylate buffer $\mathrm{pH} 9.0$ (CAC) to be sonicated at $4{ }^{\circ} \mathrm{C}$ for $60 \mathrm{~s}$ (Branson, model B15, Danbury, CT, USA). The cell lysate was centrifuged at $27000 \mathrm{~g}$ for $20 \mathrm{~min}$ at $4^{\circ} \mathrm{C}$ and the resulting hemocyte lysate supernatant (HLS) used for the assays.

\section{Assay of PO activity}

HLS phenoloxidase (PO) activity was measured spectrophotometrically by recording the product obtained from the reaction between DOPA-quinone and 3-methyl2-benzothiazolinone hydrazone hydrochloride (MBTH). ${ }^{43}$ Briefly, $40 \mu \mathrm{l}$ of HLS were incubated $20 \mathrm{~min}$ at $20^{\circ} \mathrm{C}$ with $150 \mu \mathrm{l}$ cacodilate (CAC) buffer, and $150 \mathrm{ml}$ MBTH reaction mixture, containing $0.49 \mathrm{ml}$ of buffer B ( $4 \% \mathrm{~N}, \mathrm{~N}^{\prime}$ dimethylformamide in CAC buffer), $0.2 \mathrm{ml}$ of $5 \mathrm{~mm}$ dihydroxyphenylalanine (L-DOPA) and $0.3 \mathrm{ml}$ of $20.7 \mathrm{~mm} \mathrm{MBTH}$ in buffer B (DOPAMBTH). After incubation, the reaction product was detected at $505 \mathrm{~nm}$.

The effect of protease as a proPO activator (bovine pancreas trypsin type III) was examined by adding $150 \mu$ l of enzyme $\left(1 \mathrm{mg} \mathrm{ml}^{-1}\right.$ in CAC) to $40 \mu \mathrm{lLS}$. After $20 \mathrm{~min}$ preincubation, $150 \mu \mathrm{l}$ of L-DOPA were added into the reaction mixture. The spectrophotometric measures were compared with controls, in which protease solutions were substituted by $150 \mu \mathrm{l}$ of CAC-buffer. The PO activity was expressed as units $(\mathrm{U})$ for min where $1 \mathrm{U}=0.001 \mathrm{DA}_{505} \mathrm{~min}^{-1} \mathrm{mg}^{-1}$ protein.

\section{Protein determination}

Protein content was determined using the Bradford method, ${ }^{44}$ with bovine serum albumin (BSA) as a standard. The HLS protein content ranged from 20 to $100 \mu \mathrm{g} \mathrm{ml}^{-1}$.

\section{Cytochemical PO assay}

Hemocytes suspended in MS were layered on a cleaned pyrogen-free (heated at $180^{\circ} \mathrm{C}$ for $4 \mathrm{~h}$ ) glass coverslip and incubated for $30 \mathrm{~min}$ at $20^{\circ} \mathrm{C}$. Cell monolayers were washed three times with FSW and fixed for $30 \mathrm{~min}$ with $1 \%$ glutaraldehyde in MS containing $1 \%$ sucrose. Finally, after three washings in distilled water, cell monolayers were incubated with DOPA-MBTH and observed after 1-8 h using an inverted microscope. A visible pink product was observed when MBTH reacted with dopaquinones. ${ }^{43}$

\section{Hemocyte cytotoxic assay (HCA)}

The cytotoxic assay against erythrocytes has been described previously. ${ }^{8}$ In brief, $200 \mu \mathrm{l} \mathrm{S}$. plicata hemocyte suspensions $\left(1.5 \times 10^{6}\right.$ cells, Effector $)$ in MS were mixed with an equal volume of freshly prepared rabbit erythrocytes $\left(8 \times 10^{6}\right.$ cells, REs) in the same medium. The mixture was incubated at $20^{\circ} \mathrm{C}$ for $1 \mathrm{~h}$, and the amount of the released hemoglobin was estimated by reading the absorbance at $541 \mathrm{~nm}$ in the supernatants after mixture centrifugation. To obtain $100 \%$ hemolysis, $8 \times 10^{6}$ REs were suspended in $200 \mu \mathrm{l}$ distilled water and frozen before being centrifuged at $800 \mathrm{~g}$ to separate 
ghosts. When REs were suspended in MS, the spontaneous hemoglobin release never exceeded $5 \%$ of the total release.

The degree of hemolysis was determined according to the equation:

$$
\begin{aligned}
& \text { percentage hemolysis } \\
& \qquad=\frac{\text { measured release }- \text { spontaneous release }}{\text { complete release }- \text { spontaneous release }} \times 100
\end{aligned}
$$

\section{Fluorescence quenching for in vitro phagocytosis assay}

Assays, using Saccharomyces cerevisiae (Sigma) as target, were performed according to Cooper et al. ${ }^{24}$ with slight modifications. The yeast cells were prepared in distilled water (d.w.) as a $0.25 \%(\mathrm{w} / \mathrm{v}$, suspension, approximately $1 \times 10^{7}$ cells $\mathrm{ml}^{-1}$ ) autoclaved for $15 \mathrm{~min}$, washed twice at $2000 \mathrm{~g}$ at $4{ }^{\circ} \mathrm{C}$ for $5 \mathrm{~min}$, and incubated for $1 \mathrm{~h}$ at $20^{\circ} \mathrm{C}$ with eosin $\mathrm{Y}$ (4-bromo-fluorescein) at $0.05 \%$ final concentration. Yeast cells were washed four times, suspended to a final concentration of $0.125 \% \mathrm{w} / \mathrm{v}$ in phosphate buffer saline (PBS, $6 \mathrm{mM} \mathrm{KH} \mathrm{KO}_{4}, 30 \mathrm{mM} \mathrm{Na} \mathrm{HPO}_{4}, 0.11 \mathrm{M} \mathrm{NaCl}, \mathrm{pH}$ 7.4) and stored at $20^{\circ} \mathrm{C}$ for a maximum of 2 weeks. Yeast and $100 \mu \mathrm{l}$ hemocyte suspension in MS $\left(2.5 \times 10^{6}\right.$ cell $\left./ \mathrm{ml}\right)$ were placed $(\mathrm{v} / \mathrm{v})$ in a $1 \mathrm{ml}$ plastic tube and incubated ( $1: 4$ yeast/hemocyte ratio) for $30 \mathrm{~min}$ at $20^{\circ} \mathrm{C}$ with gentle stirring, then $50 \mu \mathrm{l}$ of the quenching solution $\left(2 \mathrm{mg} \mathrm{ml}^{-1}\right.$ trypan blue, $2 \mathrm{mg} \mathrm{ml}^{-1}$ crystal violet in 0.02 citrate buffer, pH 4.4 containing $33 \mathrm{mg} \mathrm{ml}^{-1} \mathrm{NaCl}$ ) was added. Phagocytes containing fluoresceinated yeasts were observed under a microscope equipped with Nomarski differential interference contrast optics and fluorescent apparatus (450-490 nm filter; Diaplan, Leika, Wetzlar, D); about 200 cells in each slide were counted at $800 \times$ magnification. The results were expressed as the percentage of cells containing yeasts.

\section{Exposure of hemocytes to methylmercury in microplate}

Hemocytes were aliquoted $(100 \mu \mathrm{l}$ for well) into 96-well flat-bottomed cell culture plates, where hemocytes (from $2.5 \times 10^{6}$ cell ml $^{-1}$ to $7.5 \times 10^{6} \mathrm{cell} \mathrm{ml}^{-1}$ ) were maintained at $15^{\circ} \mathrm{C}$ for $1 \mathrm{~h}$. For microplate exposures, various concentration of methylmercury $\left(10^{-4}-10^{-8} \mathrm{M}, 10 \mu \mathrm{l}\right.$ FSW per well) were added to cultured hemocytes. Hemocyte aggregates could be seen on the well bottom following the treatment, and the effect of xenobiotic concentration was evaluated by direct observation.

The hemocyte mortality after $1 \mathrm{~h}$ exposure to $\mathrm{CH}_{3} \mathrm{HgCl}$ at the concentrations used, as evaluated by the Trypan blue test, was $<5 \%$, whereas cell viability, checked by neutral red vital stain, ${ }^{45}$ was $>95 \%$.

Hemocytes were layered on a slide and their morphology observed under Nomarski differential interference contrast microscopy (Diaplan, Leika, Wetzlar, D).

\section{Statistical analysis}

Unless otherwise indicated, the experiments were repeated three times. The values were the means of three assays performed in triplicate \pm SD. Significance was determined with Student's $t$-test and differences between results were considered significant at $p<0.05$.

\section{RESULTS}

\section{Nontoxic doses of methylmercury activate hemocyte prophenoloxidase}

Since hemocyte exposure to methylmercury concentrations higher than $2 \times 10^{-4} \mathrm{M}$ caused a significant increase in cell mortality $\left(14 \%\right.$ dead and $78 \%$ living cells at $\left.10^{-3} \mathrm{M}\right)$ the experiments were performed at sublethal concentrations $\left(10^{-4}-10^{-8} \mathrm{M}\right)$ when about $95 \%$ viable cells and $<5 \%$ dead cells were found using neutral red and Trypan blue tests.

Methylmercury activated hemocyte proPO in a dosedependent fashion, as shown by the increased PO activity found in the hemocyte lysate supernatant (Fig. 1). Significant activation $(p<0.05)$ vs nontreated hemocytes was already evident $(65.9 \pm 1.32)$ when the methylmercury concentration was $10^{-6} \mathrm{M}$. The activity further increased $(72.4 \pm 1.1)$ at $10^{-5} \mathrm{mM}$ and reached a high level $(79.3 \pm 1.3)$ at $10^{-4} \mathrm{M}$ $(p<0.01)$. This effect was similar to proPO activation due to treatment with trypsin that is known to be the best activator $(89.1 \pm 5.0, p<0.001)$. Quinone production (Abs at $505 \mathrm{~nm}$ ) became asymptotic within 25-30 min after the addition of DOPA-MBTH mixture (Fig. 1).

\section{Effects of methylmercury on hemocyte cytotoxic activity}

Figure 2 shows the methymercury effect on cytotoxic hemocytes assayed with REs in the presence of increasing

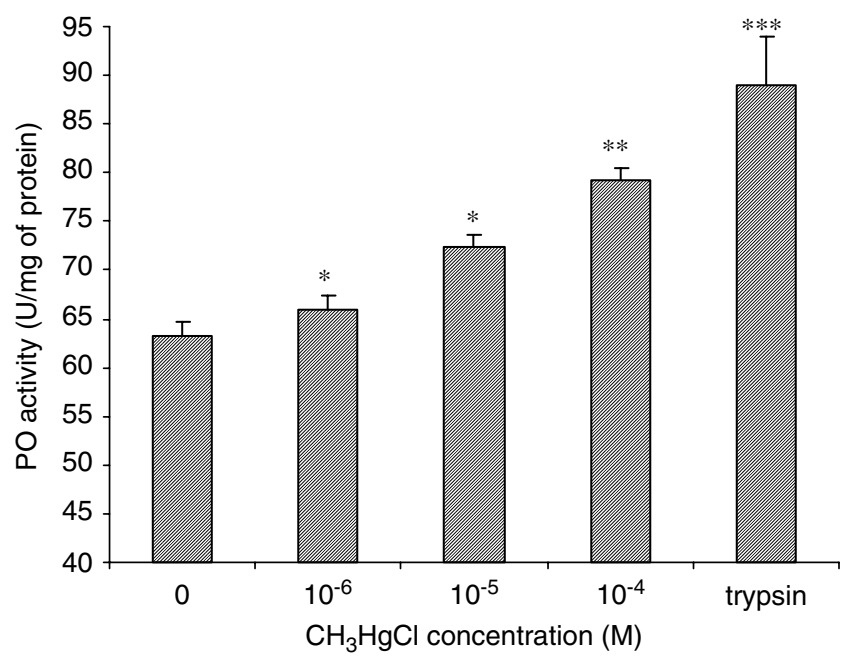

Figure 1. Effect of various methylmercury concentrations on the PO activity (A505) of hemocyte lysate supernatant after S. plicata hemocytes were incubated for $1 \mathrm{~h}$ in vitro with xenobiotic. Bars represent SD, $n=8$. ${ }^{*} p>0.05$; ${ }^{* *} p>0.01$; ${ }^{* * *} p>0.001$. 


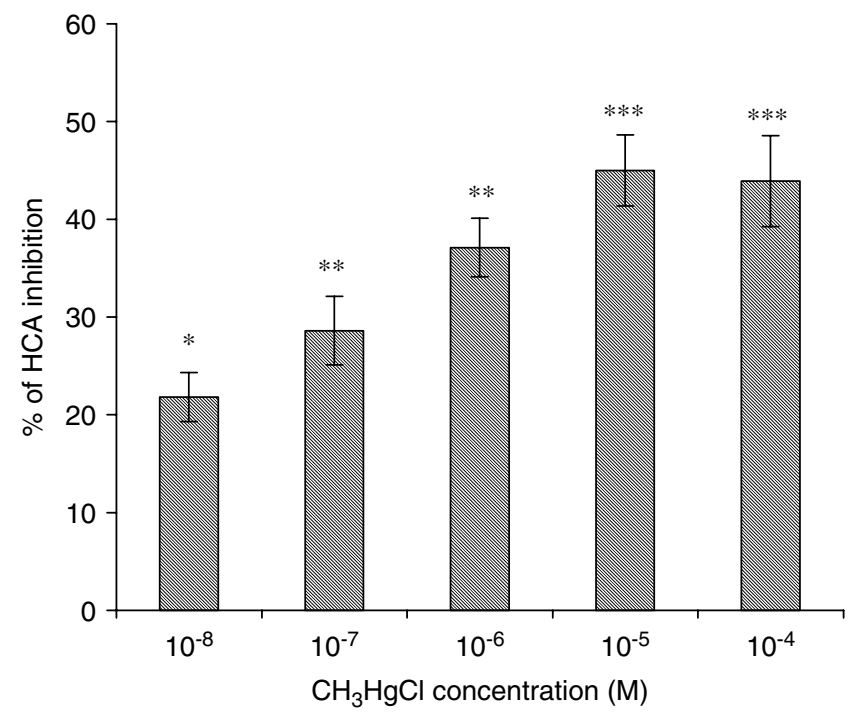

Figure 2. Effect of various methylmercury concentrations on S. plicata hemocyte cytotoxic activity $(\mathrm{HCA})$, against rabbit erythrocytes after incubation of hemocytes for $1 \mathrm{~h}$ in vitro with xenobiotic. Bars represent $\mathrm{SD}, n=8$. ${ }^{*} p>0.05$; ${ }^{*} p>0.01$; *** $p>0.001$.
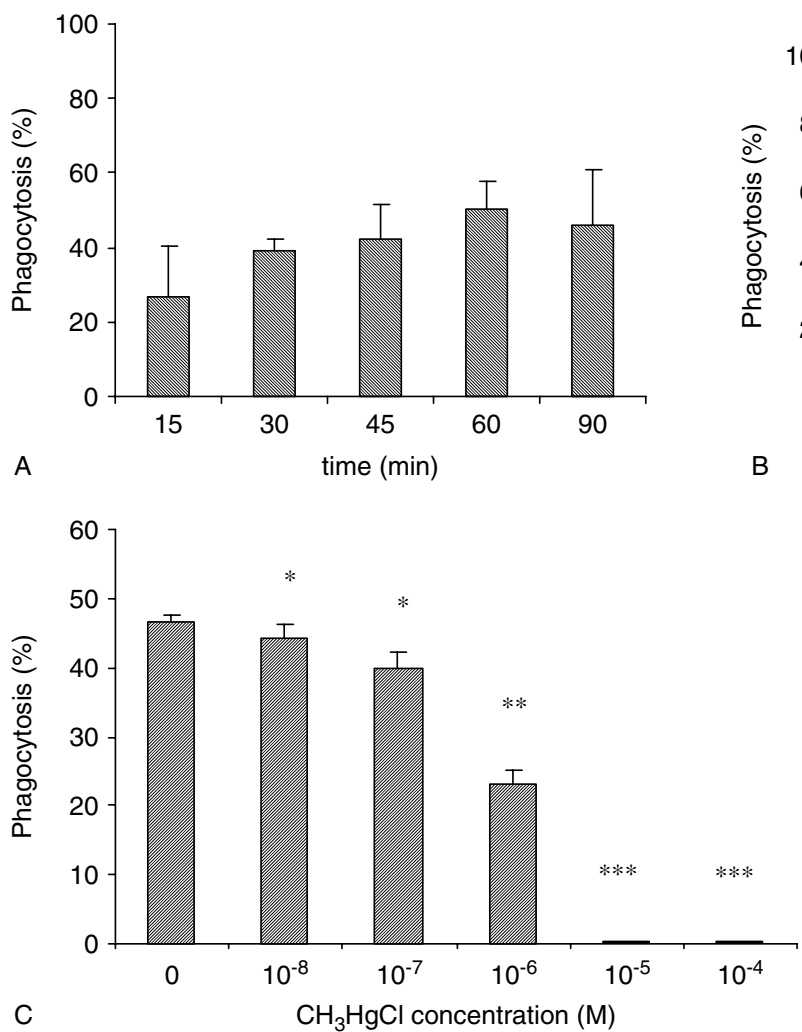

methylmercury concentrations $\left(10^{-8}-10^{-4} \mathrm{M}\right)$. The activity of $7.5 \times 10^{6}$ cells $\mathrm{ml}^{-1}$ (effector/target ratio, i.e. $\mathrm{E}: \mathrm{T}=1: 5$ ) was significantly inhibited in a dose-dependent fashion, reaching the lowest level at $10^{-4} \mathrm{M}(p<0.001)$, whereas, at the lowest xenobiotic concentration $\left(10^{-8} \mathrm{M}\right)$, the inhibition level presented a low significance value $(p<0.05 ; 21.82 \%)$ compared with the control. The activity of the cells exposed to higher concentrations $\left(10^{-4} \mathrm{M}\right)$ decreased by up to $19 \%$ $(p>0.001)$. At different hemocyte numbers, the inhibition ranged from about $50 \%\left(3.75 \times 10^{6}\right.$ cell ml $\left.^{-1} ; \mathrm{E}: \mathrm{T}=1: 10\right)$ to $38 \%\left(15 \times 10^{6} \mathrm{cell} \mathrm{ml}^{-1} ; \mathrm{E}: \mathrm{T}=1: 2.5\right)$ depending on the effector : target ratio.

\section{Effect of methylmercury on phagocytic activity}

Figure 3(A, B) shows that the highest phagocytic activity was achieved when $2.5 \times 10^{6}$ cells ml $^{-1}$ were incubated with yeast for $60 \mathrm{~min}$ at $20^{\circ} \mathrm{C}$. The effects on phagocytic activity of hemocytes exposed in vitro to methylmercury are presented in Fig. 3(C). Figure 3(D) shows hemocytes with phagocytosized yeast as observed for their fluorescence. After just $1 \mathrm{~h}$ of hemocyte incubation with the xenobiotic, the phagocytic activity was significantly lowered $(p<0.05)$ by $10^{-8}$ and $10^{-7} \mathrm{M}$ methylmercury, reaching the lowest level $(p<0.001)$
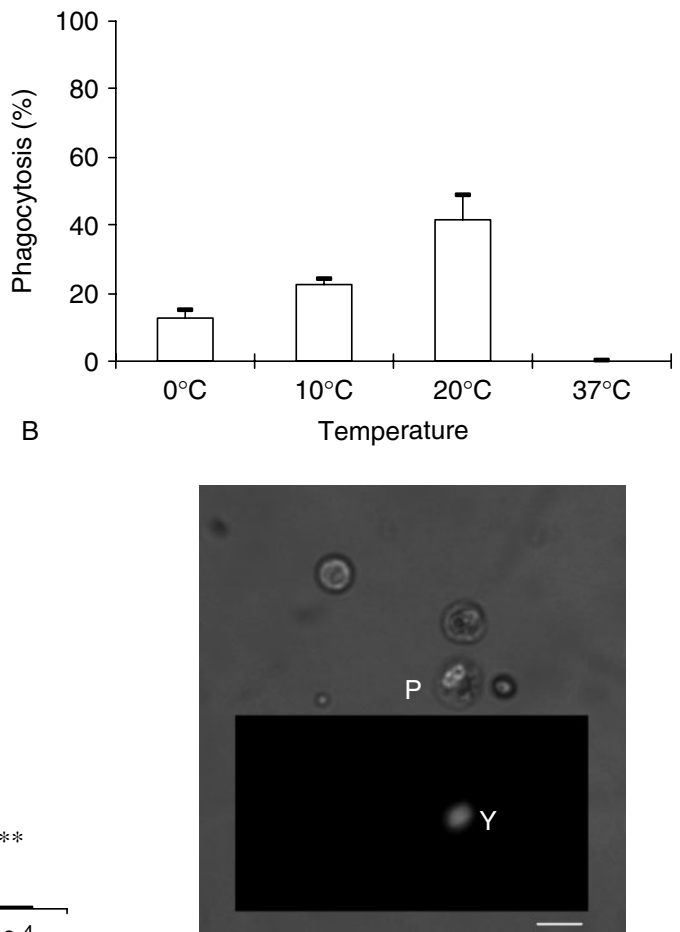

D

Figure 3. In vitro phagocytosis of yeast cells (Saccharomyces cerevisiae) by S. plicata hemocytes. Phagocytosis was evaluated as the percentage of hemocytes contaning yeast (\% phagocytosis). (A) Percentage of phagocytes in absence of xenobiotic; (B) phagocytic response of hemocytes at different temperatures; (C) percentage of phagocytes after hemocyte exposure to different methylmercury concentrations; (D) light microscopy observation of phagocytes $(P)$; in the inset fluorescent yeasts $(Y)$ are shown. Bar $=10 \mu \mathrm{m}$. ${ }^{*} p>0.05 ;{ }^{* *} p>0.01 ;{ }^{* * *} p>0.001$. 
in the presence of $10^{-6} \mathrm{M}$, and it was significantly decreased by $10^{-5} \mathrm{M}(p<0.001)$.

\section{Cell morphology modification after methylmercury exposure}

When $5 \times 10^{6}$ cell ml $\mathrm{m}^{-1}$ hemocytes were layered in the wells of a U-bottomed chamber containing decreasing methylmercury concentrations (from $10^{-4}$ to $10^{-7} \mathrm{M}$ ), changes in cell morphology and spreading appeared at a macroscopical level as variously shaped disk of cells [Fig. 4(A)]. Microscopy observations of the hemocytes layered on the well bottom showed that, in the absence of methylmercury, the hemocytes presented a spread shape showing an irregular morphology [Fig. 4(B)]. After treatment with methylmercury at a low concentration $\left(10^{-4}\right)$ the hemocytes presented a round shape [Fig. 4(C)]. Similar results were obtained when treatments were directly performed on a slide.

As shown in Fig. 4(D, E), PO-positive morula cells were identified by cytochemical reaction with DOPA-MBTH. An untreated spread morula cell is shown in Fig. 4(D), whereas Fig. 4(E) presents a round methylmercury-treated cell with more intense DOPA-MBTH stain.

Since PO-containing cells could release the enzyme after methylmercury treatment, the PO activity of hemocyte culture medium was compared with that of the cultured hemocytes. Data listed in Table 1 show that the PO activity found in the medium was significantly lower than that of the HLS. In addition, cell treatment with methylmercury significantly $(p<0.001)$ enhanced the activity of both the released $(25 \%$ enhancement) and cytoplasmic (27\% enhancement) PO.

\section{DISCUSSION}

Tunicates are filter-feeding marine invertebrates ubiquitous throughout the world. They live along the coast and can be subjected to environmental contaminats such as toxic metals, including the methylated form of mercury, that could affect their innate immune system. According to previous reports, xenobiotics could activate or suppress the immune functions. A decreased immunoreactivity, i.e. phagocytosis and cytotoxicity, affects the preservation of organism health, whereas it is unclear if activation of components of the immune system may affect the organism immunesurveillance

Table 1. PO activity of $S$. plicata hemocytes $\left(10^{7}\right.$ cells $\left.\mathrm{ml}^{-1}\right)$ treated for $1 \mathrm{~h}$ with $10^{-5} \mathrm{M}$ methylmercury. Hemocyte culture medium and hemocyte lysate supernatant (HLS) were examined; $n=8$

\begin{tabular}{lccc}
\hline & PO activity $\left(\mathrm{U}_{\mathrm{A} 505} \mathrm{mg}^{-1}\right.$ protein $)$ & Increase \\
\cline { 2 - 3 } & Control & Methylmercury & $(\%)$ \\
\hline Culture medium & $35.4 \pm 2.9$ & $45.7 \pm 2.8(p<0.001)$ & $(25.9)$ \\
HLS & $63.3 \pm 5.2$ & $80.3 \pm 3.2(p<0.001)$ & $(27.8)$ \\
\hline
\end{tabular}

Copyright $@ 2007$ John Wiley \& Sons, Ltd.
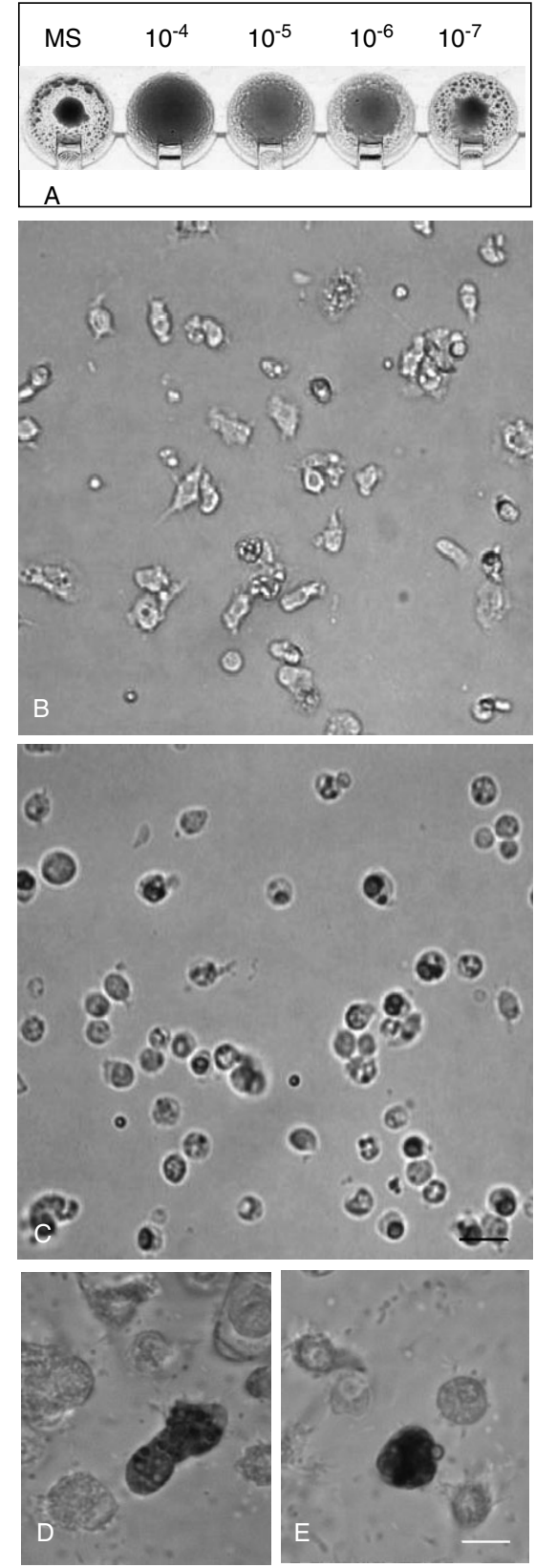

Figure 4. Effect of methylmercury on S. plicata hemocyte morphology. (A) Macroscopical test of hemocytes from hemolymph after $1 \mathrm{~h}$ of preincubation with different methylmercury concentrations; (B) control: hemocytes maintained for $1 \mathrm{~h}$ in marine solution in absence of xenobiotic; (C) light microscopy observations of hemocytes after $1 \mathrm{~h}$ treatment with methymercury $\left(10^{-6} \mathrm{M}\right)$; (D) phenoloxidase activity of hemocytes maintained in MS in the absence of methylmercury, as revealed by DOPA-MBTH mixture; (E) PO activity of hemocytes treated for $1 \mathrm{~h}$ with $10^{-6} \mathrm{M}$ methylmercury, as revealed by MBTH mixture; $\mathrm{B}$ and $\mathrm{C}$, bar $=20 \mu \mathrm{m} ; \mathrm{D}$ and $\mathrm{E}$, spot bar $=10 \mu \mathrm{m}$.

capacity. In ascidians, phagocytosis, ${ }^{46}$ the prophenoloxidase system $^{42}$ and cytotoxic ${ }^{47}$ activities are the main cellular 
immune mechanisms exerted by hemocytes circulating in the hemolymph for defending the organism against several pathogens that could penetrate through pharynx filtrating action. Ascidians undergo the effect of environmental xenobiotics and bioaccumulate metals, becoming chronically exposed to their action.

In the present paper, we examined the effects in vitro of methylmercury, at sublethal concentrations, on Styela plicata hemocyte phenoloxidase, cytotoxic and phagocytic activities. In addition, since cell morphology and spreading hemocyte ability can be related to immune functions, these features were taken into consideration. The methylmercury concentrations we used for examining the effect on immunocytes were not toxic, as indicated by Trypan blue dead cell exclusion test, while viability was not affected by the treatment, as shown by the neutral red test. In general terms, 95\% hemocytes maintained their main viable properties, whereas immune functions were affected by the xenobiotic compound. The phenoloxidase activity was examined in the lysate supernatant from hemocytes treated with different methylmercury amounts. In the range of $10^{-4}-10^{-8} \mathrm{M}$, the xenobiotic enhanced the PO activity in a dose-dependent fashion, suggesting that the pro-phenoloxidase system could be activated even if at a level lower than that observed by a treatment with a serine protease (trypsin), which is known to be a good activator of the proPO pathway. ${ }^{48}$ Similar results have been reported using fruoranthene on Mytilus edulis hemocyte PO. ${ }^{49}$

In S. plicata, phenoloxidase activity is a property of morula cells ${ }^{50}$ which, after effector-target contacts, display PO-dependent cytotoxic activity against erythrocytes and tumor line K562 cells, probably due to quinones produced by the PO pathway. ${ }^{48}$ When hemocytes were pre-treated with $10^{-5} \mathrm{M}$ methylmercury, in spite of the PO activation, the cytotoxic activity was inhibited, suggesting that the treatment of hemocytes with the xenobiotic affects cell-target contacts, including the recognition mechanism. Accordingly, a similar xenobiotic action could be responsible for phagocytosis inhibition. Phagocytes after $1 \mathrm{~h}$ exposition to low xenobiotic concentration $\left(10^{-4}\right.$ up to $\left.10^{-5} \mathrm{M}\right)$, were viable but did not phagocytosize yeast, whereas their activity was maintained almost at control level when the cells were in the presence of a lower toxicant concentration $\left(10^{-8} \mathrm{M}\right)$.

The cytotoxicity inhibitory effect could not be imputed to a releasing mechanism, since in the presence of the xenobiotic the enzyme was released into the culture medium showing the same activity level as the controls. However, we do not know if methylmercury could also act on cytoskeletal network, as indicated by changes in hemocyte morphology and spreading capacity. With regard to this, it is known that cytoskeletal alterations lead to reduced phagocytic activity, due to the decreased ability of hemocytes to adhere to the substrate and interact with targets. ${ }^{51}$ Finally, a lipid peroxidation ${ }^{10}$ could damage the plasma membrane, affecting the activity of both phagocytes and cells of the cytotoxic line.
Effects on the cytoskeleton could be responsible for changes in the hemocyte morphology and spreading capacity, as revealed by the microplate assay we performed. Although the assay cannot reveal the xenobiotic concentration values in water, it appears to be an easy method for indicating that xenobiotics at sublethal toxicant concentration could be present.

In conclusion, we show that high environmental methylmercury concentrations are toxic for tunicate hemocytes, whereas sublethal concentrations affect the $S$. plicata immunocyte activities, causing immunosuppression, as revealed by assaying cytotoxic activity with rabbit erythrocytes and phagocytosis of yeast, which could be used as additional immunotoxicology biomarkers in macrobenthic studies.

\section{Acknowledgments}

This work was supported by MIUR and University of Palermo grants.

\section{REFERENCES}

1. Lawrence DA. Toxicol. Appl. Pharmac. 1981; 57: 439.

2. Zelikoff JT. Modul.Fish. Imm. Resp. 1994; 1: 101.

3. Lalancette A, Morin Y, Measures L, Fournier M. Dev. Comp. Immunol. 2003; 27: 735.

4. Rainbow PS, Phillips DJH. Mar. Pollut. Bull. 1993; 26: 593.

5. Jensen S, Jernelov A. Nature 1969; 233: 753.

6. Shin E, Krenkel PA. J. Water Pollut. Control. Fed. 1976; 48: 473.

7. Nagase H, Ishicawa T, Ose Y, Sato T. Total Environ. 1982; 25: 133.

8. Cossa D, Fichet A. La dynamique du mercure. Programme scientifique Seine-Aval 1999; 11.

9. Leermakers M, Baeyens W, Quevauviller P, Horvat M. Trends Anal. Chem. 2005; 24: 383.

10. Yin Z, Milatovica D, Aschnera J, Syversenb T, Rochac J, Souzad D, Sidoryke M, Albrechte J, Aschner M. Brain Res. 2007; 1131: 1.

11. Ikingura JR, Akagi H. Sci Total Environ. 1999; 234: 109.

12. Sanchez UA, Sanz M. Talanta 1998; 47: 509.

13. Ipolyi I, Massanisso P, Sposato S, Fodor P, Morabito R. Anal. Chim. Acta 2004; 145: 151

14. Law RJ, Allchin CR, Harwood J. Mar. Pollut. Bull. 1989; 20: 110.

15. Bayne BL, Brown DA, Burns K, Dixon DR, Ivanovici A, Livingstone DR, Lowe DM, Moore MN, Stebbing AR, Widdows J. The Effects of Stress and Polution on Marine Animals. Prager Scientific, 1985.

16. McCarthy F, Shugart LR. Biomarkers of Environmental Contamination. Lewis: Chelsea, USA, 1990.

17. Sanders BM. Crit. Rev. Toxicol. 1993; 23: 49.

18. Wong S, Fournier M, Coderre D, Banska W, Krzystyniak K. Animal Biomarkers as Pollution Indicators, Peakall D (ed.). Chapman and Hall: London, 1992; 291.

19. Depledge MH, Fossi MC. Ecotoxicology 1994; 3: 161.

20. Monniot F, Martoja R, Monniot C. Compt. Rend. Acad. Sci. 1993; 310: 583.

21. Monniot F, Martoja R, Monniot C. Ann. Inst. Océanogr. 1994; 70: 205.

22. Cima F, Ballarin L, Bressa G, Martinucci G, Burighel P. Ecotoxicol. Environ. Saf. 1996; 35: 174.

23. Raftos DA, Hutchinson AE. Biol. Bull. 1997; 192: 62.

24. Cooper EL, Arizza V, Cammarata M, Pellerito V, Parrinello N. Comp. Biochem. Physiol. 1995; 112.

25. Tujula N, Radford J, Nair S, Raftos D. Aquat. Toxicol. 2001; 55: 191. 
26. Cheng TC. Comp. Pathobiol. 1977; 3: 21.

27. Krzystyniak K, Flipo D, Mansour S, Fournier M. Immunopharmacology 1989; 18: 157.

28. Flipo D, Bernier J, Girard D, Krzystyniak K, Fournier M. Int. J. Immunopharmac. 1992; 14: 747.

29. Wong S, Fournier M, Coderre D, Banska W, Krzystyniak K. Animal Biomarkers as Pollution Indicators. Peakall D (ed.). Chapman and Hall: London 1992; 167.

30. Voccia I, Krzystyniak K, Dunier M, Flipo D, Fournier M. Aquat. Toxicol. 1994; 29: 27.

31. Brousseau P, Pellerin J, Morin Y, Cyr D, Blakley B, Boermans H. Toxicology 2000; 142.

32. Fagotti A, Di Rosa I, Simoncelli F, Pipe Rk, Panara F, Pascolini R. Dev. Comp. Immunol. 1996; 20: 383.

33. Fugere N, Brousseau P, Krzystyniak K, Coderre D, Fournier M. Toxicology 1996; 109: 157.

34. Sauvè S, Hendawi M, Brousseau P, Fournier M. Ecotoxicol. Environ. Saf. 2002; 52: 21

35. Sauvè S, Fournier M. Ecotoxicol. Environ. Saf. 2005; 60: 67.

36. WHO IPCS (International Programme on Chemical Safety). Environmental Health Criteria. Methylmercury. World Health Organization: Geneva, 1990; 35.

37. Leonard I, Sweet JT Zelikoff J. J Toxicol. Environ. Health 2001; 4: 161.
38. Johansson MW, Söderhäll K. Parasitol. Today 1989; 5: 171.

39. Söderhäll K, Cerenius L. Curr. Opin. Immunol. 1998; 10: 23.

40. Pang QX, Zhang SC, Wang CF, Shi XD, Sun YN. Fish Shellfish Immunol. 2004; 17: 477.

41. Nappi AJ, Vass E. Pigment Cell Res. 1993; 6: 117.

42. Cammarata M, Arizza V, Vazzana M, Parrinello N. It. J. Zool. 1996; 63: 345.

43. Winder J, Harris H. Eur. J. Biochem. 1991; 198: 317.

44. Bradford MM. Anal. Biochem. 1976; 72: 248

45. Borenfreund E, Puerner JA. Mar. Environ Res. 1984; 14: 317.

46. Wright RK. Invertebrate Blood Cells, Ratcliffe NA, Rowley AF (eds), Vol. 2. Academic Press: London, 1981; 565-626.

47. Parrinello N. 1996 Invertebrate Immunology, Rinkevich B, Muller W (eds). Springer: Berlin, 1990.

48. Cammarata M, Arizza V, Candore G, Caruso C, Parrinello N. Eur. J. Cell Biol. 1997; 302.

49. Coles JA, Pipe RK. Fish Shellfish Immunol. 1994; 4: 337.

50. Arizza V, Cammarata M, Tomasino MC, Parrinello N. I. Inv. Pathol. 1995; 66: 297.

51. Matozzo V, Ballarin L, Pampanin DM, Marin MG. Environ. Contam. Toxicol. 2001; 41: 163 